ENTREPRENEURSHIP AND SUSTAINABILITY ISSUES

ISSN 2345-0282 (online) http://jssidoi.org/jesi/ 2019 Volume 7 Number 1 (September) http://doi.org/10.9770/jesi.2019.7.1(8)

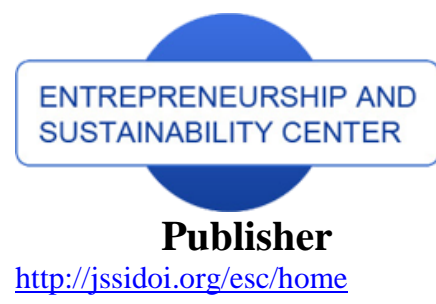

http://jssidoi.org/esc/home
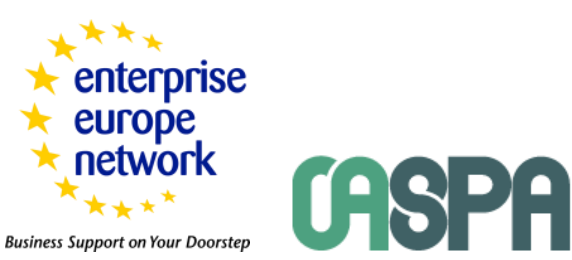

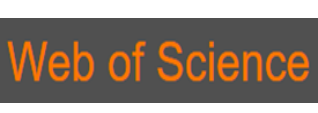

Clarivate

Analytics

\title{
IMPROVING THE EFFICIENCY OF THE NEGOTIATION PROCESS IN THE SOCIAL PARTNERSHIP SYSTEM
}

\author{
Mikhail V. Vinichenko ${ }^{1 *}$, Dmitry S. Klementyev ${ }^{2}$, Marina V. Rybakova ${ }^{3}$, Maksim A. Malyshev ${ }^{4}$, Natalia F. \\ Bondaletova $^{5}$, Inna V. Chizhankova ${ }^{6}$ \\ 1,5,6 Russian State Social University, Str. Vil'gel'ma Pika, 4, 1, 129226 Moscow, Russia \\ ${ }^{2,3,4}$ Lomonosov Moscow State University, Leninskie Gory, Moscow, 119991 Moscow, Russia \\ E-mails: ${ }^{1 *}$ mih-vas2006@yandex.ru
}

Received 10 January 2019; accepted 28 June 2019; published 30 September 2019

\begin{abstract}
The article deals with the issues of increasing the efficiency of the negotiation process in the system of social partnership by optimizing a single negotiating company at the local level of social partnership. The developed methodology relies on a system of methods, the main of which are an online survey, content analysis and a focus group using the Likert method. The article for the first time summarized the experience on the implementation of a unified transnational campaign in the subsections of the Russian Federation (RF), evaluated the existing mechanisms used in social protection interests of workers. The analysis of the subjective and objective factors allowed the authors to reveal that the increase in the efficiency of the unified translational complex is impeded the desire for independence and independence of a number of trade union leaders. In the negative sector was the implementation of agreements (regional and sectoral). It requires the development of awareness of trade union functionaries. In the interests of increasing the efficiency of the negotiation process, it was proposed to improve the information system for providing trade union leaders; social protection issues should be addressed at their own levels. The main advantage of the article is that it points to the substantial dependence of the negotiation process on the subjective factor - trade union leaders. It is important to encourage them to conduct comprehensive work in the framework of the implementation of the basic principles of the negotiation campaign, focusing on the increase in wages, the subsistence minimum and the need to strengthen control, both from trade unions and from government bodies. The development of trade union leaders should focus on gaining knowledge and practical experience in negotiating, studying the regulatory framework. At the same time, they need to learn how to enlist the support of the team from the higher authorities. The harmonious development of all elements of the negotiation process will serve as a guarantee of increasing the efficiency and effectiveness of social partnership.
\end{abstract}

Keywords: efficiency, negotiations, trade union, leaders, social sphere, social partnership, social dialogue

Reference to this paper should be made as follows: Vinichenko, M.V.; Klementyev, D.S.; Rybakova, M.V.; Malyshev, M.A.; Bondaletova, N.F.; Chizhankova, I.V. 2019. Improving the efficiency of the negotiation process in the social partnership system, Entrepreneurship and Sustainability Issues 7(1): 92-104. http://doi.org/10.9770/jesi.2019.7.1(8)

\section{Introduction}

In the context of the global economic crisis, business faces the problem of increasing competitiveness. Its resolution depends on many factors, the most important of which is company employees. Owners and managers of organizations need to find the keys to improving staff efficiency, loyalty, and commitment to corporate values (Buley at al., 2016). In this system, the state also has an obligation to take care of citizens, provide them with 


\section{ENTREPRENEURSHIP AND SUSTAINABILITY ISSUES}

ISSN 2345-0282 (online) http://jssidoi.org/jesi/ 2019 Volume 7 Number 1 (September) http://doi.org/10.9770/jesi.2019.7.1(8)

suitable work, create favorable working conditions and livelihoods. The socio-economic situation makes it difficult for the government and business to fulfill their obligations (Buley, Bondaletov at al., 2016; Androniceanu, 2019a). The workers themselves are often on the verge of survival and do not want to put up with a demeaning situation, disregard for their problems.

The struggle for their rights by workers is multifaceted. One of the issues is the fight against unfair treatment of employees by management in the system of motivation and stimulation of labor activity (Belle \& Cantarelli, 2015; Liu \& Perry, 2016; Vinichenko et al., 2018; Lorincová et al., 2019; Ciobanu et al., 2019), creating favorable, safe working conditions (Baxter et. Al, 2016; Rogach et al., 2016; Vinichenko et al., 2016; Bernardi, 2019), career advancement (Kataeva et al., 2015; Mysnik \& Marchelya, 2014; Demeneva, 2007; Chulanova \& Korosteleva, 2017), gender discrimination (Blossfeld \& Huinink, 1991), social ethnic conflicts (Oseev et al., 2018; Vasile \& Androniceanu, 2018).

A special place in the protection of their rights is occupied by young employees, the attitude towards which does not always correspond to the declared values (Demchenko et al., 2018; Vinichenko et al., 2017; Androniceanu, 2019b).

Practice shows that protests of workers only become effective when they are united by a center of resistance. They often become trade unions. It should be realized that the antagonistic struggle usually does not lead to the desired result. We need to compromise. The solution to a complex tangle of problems lies in the plane of social partnership (Frolova et al., 2016). All parties to a social partnership should strive to jointly address emerging issues through civilized negotiations.

One of the technologies for effective interaction within the framework of social partnership is the Unified Negotiating Company (hereinafter referred to as UNC). It is based on the observance of three basic ideas: uniform actions, uniform terms, uniform requirements. Their observance allows the primary trade union organizations to most effectively realize the potential of solidarity, take advantage of legal, consulting support of territorial and sectoral trade unions. It is important to gain trust from all parties involved in the negotiation process (Rogach, Frolova \& Ryabova, 2018).

The developed approaches make it possible to streamline the negotiation process in Russia, to consolidate the efforts of trade unions to achieve greater effect in the negotiation process. At the same time, the most important conditions for the formation of a truly partnership are goodwill, free expression of one's own opinion and the practice of collective decision-making (Rogach, et al., 2018). Employees covered by traditional forms of labor relations, as noted in the studies, are more protected in the labor market (Precarious Employment in Europe, 2016). Data from the International Labor Organization show that traditional labor relations cover no more than one-quarter of workers (World Employment and Social Outlook, 2015), which adversely affects daily and work life (Rodgers, 1989), the formalization of relationships between people (Mühlberger, 2009; Borisov et al., 2018). Many researchers describe negative manifestations of precarious work (Fudge, 2011), which can affect any employees (Sciarra, 2004; Schmidt, 2002).

An important aspect of improving the effectiveness of the negotiation process in the system of social partnership is the level of education, preparedness, personal, leadership qualities of the trade union leader. The most important condition for the success of a trade union leader is its continuous development (Kirillov et al., 2017; Bondaletova et al., 2018), the use of modern self-improvement technologies and the development of leadership qualities (Bronkhorst et al., 2015).

Thus, an analysis of the available literature has shown that certain aspects of this problem have been disclosed, but there is no generalizing work. The high need to improve the efficiency of the negotiation process in the 


\section{ENTREPRENEURSHIP AND SUSTAINABILITY ISSUES}

ISSN 2345-0282 (online) http://jssidoi.org/jesi/ 2019 Volume 7 Number 1 (September) http://doi.org/10.9770/jesi.2019.7.1(8)

system of social partnership at the local level and the lack of ready-made recommendations for its optimization has caused the need for this study.

\section{Methodology}

The purpose of the study is to increase the efficiency of the negotiation process in the system of social partnership by improving the single negotiation campaign at the local level of social partnership - the level of the primary trade union organization.

The main tasks are based on the analysis of trade union reporting documents, the survey of trade union leaders and professional workers:

1. To summarize the experience of maintaining a single negotiation campaign in the constituent entities of the Russian Federation.

2. Assess to what extent the existing UNC mechanisms are actually applied in the social protection of the interests of the workers.

3. Analyze the subjective and objective factors hindering the effective conduct of the UNC.

4. Assess the degree of implementation of the principles of a single negotiation campaign at the level of the primary trade union organization.

The study was conducted in two stages: the first - December 2015 - December 2017, by employees of the Department of Sociology of the Department of Public Administration of the Moscow State University named after M.V. Lomonosov; the second - January 2018 - January 2019 - focus group of experts.

Hypothesis of the study - the success of a single negotiation campaign essentially depends on the local implementation of concrete actions by the parties to the social partnership for the social protection of the interests of the workers. At the same time, the creation of a more socially and effectively managed system of social protection is promoted by the formation of a social mechanism that protects equally the interests of social partners, which is possible through the negotiation process at various levels of social partnership.

The study used directional quota sampling using a comprehensive method of selecting respondents. As a result, 540 people took part in the study. Quotas were set by sex, age, status of professional workers. The respondents included: chairmen of trade union committees of enterprises, their deputies, trade union activists, as well as heads of territorial organizations of united trade unions and employees of the Central Committee of the trade union. The choice of these target groups was dictated by the need for a more complete analysis of the implementation of the EPC mechanisms. The criterion for selection of respondents was knowledge of the object of study, participation in the negotiation process.

The geographical coverage of the study extended to 19 Russian cities: Moscow, Ivanovo, Arkhangelsk, Izhevsk, Ufa, Tula, Chelyabinsk, Perm, St. Petersburg, Kirov, Kemerovo, Reutov, Nizhny Novgorod, Tyumen, Orel, Samara, Orenburg, Petrozavodsk, Saratov.

The main research methods were the questionnaire, the analysis of trade union reporting documents, the focus group. In determining the volume of the sample, the principles of design of the average sample were used, as well as expert analysis. The method of active continuous monitoring on the basis of trade union organizations in various constituent entities of the Russian Federation was used to collect and process information. The collection 
of primary information was carried out by the method of standardized questionnaires at the place of work and study of the respondents. The questionnaire survey was conducted anonymously by the method of self-filling the questionnaire. The choice of this method was dictated by the minimum influence of the interviewer on the respondents and the necessary control over the formation of the group of respondents.

Empirical data were processed using Excel and IBM SPSS Statistics 22, followed by a meaningful analysis. The results of the study are presented in the form of tables and figures, which contain the results of the analysis and statistical processing of the data obtained. At the final stage of the study, the focus group, using a comparative analysis using the Likert method, compared the data obtained with the actual state of affairs on the research problem at the beginning of 2019.

The focus group consisted of 10 experts from among domestic and foreign scientists, faculty members, and representatives of business structures. The focus of the group was the equipment that allowed the experts to exchange views with colleagues who were far away from each other and receive the necessary data from the Internet.

\section{Results}

In the course of a sociological study, it was possible to establish that a collective agreement is in a certain interaction with industry and regional agreements (Table 1).

Table 1. The relationship of the collective agreement with industry and regional agreements, $\%$

\begin{tabular}{|l|c|c|c|c|c|c|c|c|}
\hline \multirow{2}{*}{ Estimated Items } & \multicolumn{4}{|c|}{ Industry agreement } & \multicolumn{4}{|c|}{ Regional agreement } \\
\cline { 2 - 9 } & $\begin{array}{c}\text { January- } \\
\text { March }\end{array}$ & May-June & $\begin{array}{c}\text { August- } \\
\text { September }\end{array}$ & 2016 & $\begin{array}{c}\text { January- } \\
\text { March }\end{array}$ & $\begin{array}{c}\text { May- } \\
\text { June }\end{array}$ & $\begin{array}{c}\text { August- } \\
\text { September }\end{array}$ & $\begin{array}{c}2216 \\
2016\end{array}$ \\
\hline $\begin{array}{l}\text { Collective agreement: } \\
\text { Fully repeat content }\end{array}$ & 3,5 & 4,4 & 2,7 & 3,3 & 1,5 & 3,9 & 0,6 \\
\hline Repeats some clauses & 28,4 & 27,7 & 38,9 & 31,2 & $\mathbf{3 3 , 6}$ & $\mathbf{2 4 , 9}$ & $\mathbf{2 8 , 2}$ & 27,4 \\
\hline $\begin{array}{l}\text { Complements and } \\
\text { specifies its content. }\end{array}$ & $\mathbf{4 7 , 5}$ & $\mathbf{4 1 , 3}$ & $\mathbf{4 5 , 4}$ & $\mathbf{4 8 , 8}$ & 21,9 & 20,0 & 25,4 \\
\hline $\begin{array}{l}\text { Imposes restrictions on } \\
\text { the agreement. }\end{array}$ & 1,4 & 2,9 & 2,7 & 1,7 & 1,5 & 0,5 & 1,7 & 1,5 \\
\hline Not affiliated & 5,7 & 6,3 & 4,3 & 3,6 & 15,3 & 9,8 & 22,7 & 16,1 \\
\hline Difficult to answer & 13,5 & 17,5 & 5,9 & 11,4 & 26,3 & 41,0 & 21,5 & 22,9 \\
\hline
\end{tabular}

Source: Compiled by authors

During the study period, the collective agreement basically supplemented and concretized the content of sectoral and regional agreements (48.8\% and $31.7 \%$, respectively), and also repeated some of their provisions $(31.2 \%$ and $27.4 \%$, respectively).

The degree of awareness was determined using a survey (Figure 1). As a result, it was established that the awareness of trade union leaders about the UNC technology is generally high: "informed" - $27.9 \%$ and "more likely informed" $-22.6 \%$. At the same time, it was difficult to answer $4.8 \%$. 


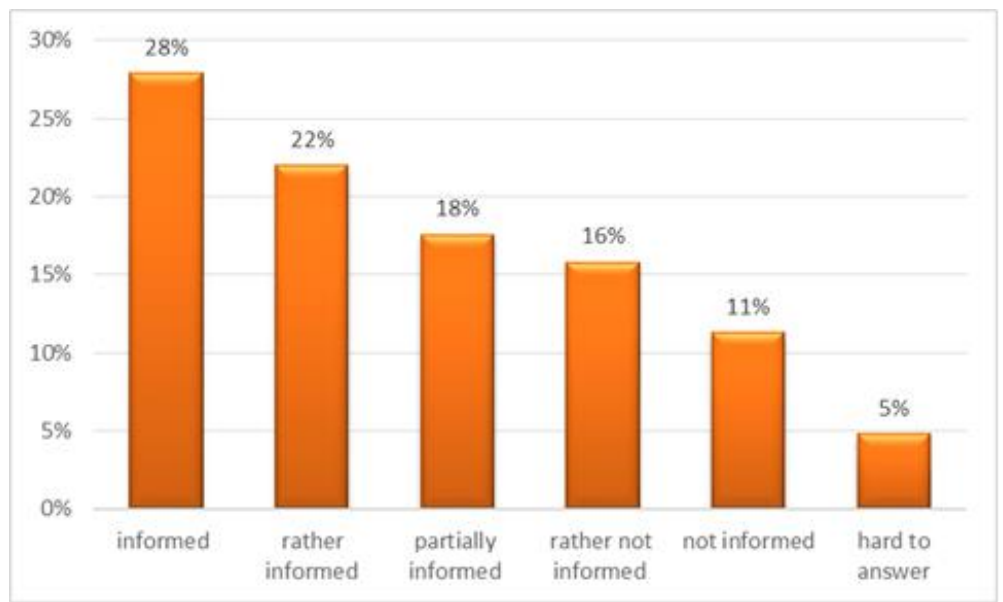

Fig.1. Awareness of trade union personnel on the EPC technology

Source: Compiled by authors

The nature of the influence of the main factors on the successful actions of the trade union leader during the negotiation process was revealed as a result of the respondents answering the question: "Indicate what, in your opinion, the trade union worker lacks to a greater extent for a single negotiation campaign?" (Table 2).

Table 2. The structure of the factors that determine the success of the trade union leader at the negotiations, $\%$

\begin{tabular}{|c|c|c|c|c|c|c|c|c|c|}
\hline № & Estimated Items & $\begin{array}{l}\text { January- } \\
\text { March }\end{array}$ & $\begin{array}{c}\text { a } \\
\text { plase }\end{array}$ & May-June & a place & $\begin{array}{c}\text { August- } \\
\text { September }\end{array}$ & a place & 2017 г. & a place \\
\hline 2. & Skills & $14,9 \%$ & 2 & $10,7 \%$ & 5 & $11,4 \%$ & 5 & $11,4 \%$ & 6 \\
\hline 4. & Team support & $14,0 \%$ & 4 & $14,5 \%$ & 2 & $17,6 \%$ & 3 & $14,2 \%$ & 4 \\
\hline 5. & Knowledge & $12,8 \%$ & 5 & $12,3 \%$ & 4 & $15,3 \%$ & 4 & $17,0 \%$ & 3 \\
\hline 6. & $\begin{array}{c}\text { Support from higher } \\
\text { authorities }\end{array}$ & $12,2 \%$ & 6 & $10,7 \%$ & 6 & $9,5 \%$ & 6 & $12,5 \%$ & 5 \\
\hline 8. & Difficult to answer & $3,9 \%$ & 8 & $4,0 \%$ & 8 & $1,7 \%$ & 8 & - & - \\
\hline 9. & General culture & $2,7 \%$ & 9 & $0,9 \%$ & 9 & $1,5 \%$ & 9 & $1,1 \%$ & 8 \\
\hline 10. & Other & $0,6 \%$ & 10 & $0,9 \%$ & 10 & $0,0 \%$ & 10 & $0,1 \%$ & - \\
\hline
\end{tabular}

Source: Compiled by authors

An analysis of the data in Table 2 showed that among the most important factors that exceeded $10 \%$ of the bar and significantly affecting the preparation and conduct of negotiations by the trade union leader in the social partnership system are: practical experience (20.4\%), regulatory framework (17.7\%), knowledge (17\%), support for the team (14.2\%), support from higher authorities (12.5), skills and abilities (11.4\%).

The focus group discussion brought the results of a sociological survey, content analysis, discussed the degree of development of the principles of a single negotiation campaign by trade union leaders. During the discussion of the results of the survey by experts, on the basis of a comparative analysis with the current state of affairs in 2019, opinions were expressed on the nature of changes in the conduct of the negotiation process by trade union leaders in the system of social partnership. There were no significant changes in the collective bargaining system - a branch agreement - a regional agreement did not occur. The collective agreement also basically complements 


\section{ENTREPRENEURSHIP AND SUSTAINABILITY ISSUES}

ISSN 2345-0282 (online) http://jssidoi.org/jesi/ 2019 Volume 7 Number 1 (September) http://doi.org/10.9770/jesi.2019.7.1(8)

and specifies the content of sectoral and regional agreements. The awareness of trade union leaders increased slightly (31\%), with a simultaneous increase in the number of those who were not fully informed (19\%) and those who found it difficult to answer (8\%). Practical experience (23\%), knowledge of the regulatory framework (19\%) and professional knowledge $(17 \%)$ remained among the main factors that significantly influenced the course of the negotiating company.

\section{Discussion}

The ratio and interrelation of different levels of the negotiation process. A single negotiation campaign is built on an integrated system of links between different levels and elements of social partnership. At the same time, labor relations are traditionally viewed through the prism of a systems approach. This goes back to the works of Dunlop J.T. (1958), Moerel H. (1994) and Salamon M.W. (1987).

However, given the influence of the state on the formation of the Russian model of social partnership, as well as the existing international specifics of the labor market - precarious employment (Cranford, Vosko \& Zukewich, 2003), incomplete, seasonal (Policies and Regulations to Combat Precarious Employment, 2011), social and labor relations local, regional (state) level (Duval \& Furceri, 2018), trace the influence and interconnection of different levels of social partnership.

Industry Agreements. Distribution of answers according to the position "Industry Agreement" shows that about half of the respondents chose the option "Complements and specifies its content". Slightly fewer respondents believe that the collective agreement repeats some provisions of the industry agreement. It is interesting to note that those who found it difficult to assess the interrelationship of the collective agreement with sectoral agreements turned out to be $11 \%$ less than under regional agreements. The structural reorganization of a number of industries and the reorganization of production under the influence of digital technologies lead to the disappearance of traditional management schemes, diversification of management decisions, expanding administrative and production boundaries of industries and enterprises (Veretekhina et al., 2018). In particular, in the countries of the European Union, according to the European Commission for March 2017, there are more than 30 projects on digitizing industry (Coordination of European, national \& regional initiatives, 2017).

All this imposes serious typos on the existing system of partnerships. Expansion of partnership forms of trade union participation in sectoral management requires strengthening the federal level of social partnership, streamlining the system of responsibility and sanctions. At the same time, we must not forget that the subject of agreement of the parties at the sectoral level should be as wide a range of issues as possible than those fixed by the relevant legislative norms. Only in this case will industry-specific agreements acquire the status of selfsufficient legal acts.

Regional agreements. Compared to sectoral agreements, regional agreements cover the problems of social sphere regulation at the level of a constituent entity of the Russian Federation much more, taking into account the emerging regional specifics. Distribution of answers shows that, in the opinion of approximately every third respondent, this legal act "Complements and specifies the content of the collective agreement". In general, there is an increase in the number of respondents who choose this answer. Alarmingly, a rather large percentage of respondents $(16.1 \%)$, who indicated that the collective agreement "is not related to a regional agreement". It is interesting to note that a rather large percentage of respondents (33\%) representing this group, in assessing the degree of interaction with higher trade union organizations, indicated the position "Situational Contacts". 24\% of their number indicated that they have no contacts "Permanent contacts" - $18 \%$.

As can be seen from the distribution presented throughout the study period, there is a steady trend towards an insufficiently high degree of implementation of agreements at various levels. In the general structure of the 


\section{ENTREPRENEURSHIP AND SUSTAINABILITY ISSUES}

ISSN 2345-0282 (online) http://jssidoi.org/jesi/ 2019 Volume 7 Number 1 (September) http://doi.org/10.9770/jesi.2019.7.1(8)

answers according to the number of agreements mentioned, the "not implemented" group prevails (rating - 3 points), this includes: regional agreement, branch agreement, territorial agreement.

According to the "Collective Agreement" position, the answers were distributed as follows. Among those who took part in the survey, $97 \%$ of respondents answered unequivocally yes that they had a collective agreement.

The majority of respondents $(67.5 \%)$ believe that this legal act is being implemented. $1.9 \%$ found it difficult to answer the question. Obviously, in the light of the problem being investigated, the implementation of collective agreements is largely determined by the presence of specific mechanisms for the local regulation of social and labor relations. These mechanisms are much more dynamic than centralized regulation. They are promptly tested and applied in the same place where they are used and are the most reliable and real collective means of protection by workers of their rights. Sometimes they carry out anticipatory regulation. This is not the case with higher level agreements.

The practice of implementing agreements (regional and sectoral) shows that the trade union side here faces serious difficulties. Exactly with the theoretical provisions of A. Kalleberg (2014), the obligations to reduce wage arrears and economic growth remain unfulfilled.

Considering the place of a regional agreement in the hierarchy of normative acts, its legal nature can be noted that in a number of agreements the problem of their implementation and the responsibility of the parties are not fully resolved. R. Hyman notes the dependence of the collective representation of workers on sectors and professions (Hyman, 1995).

It is also impossible to exclude the reasons caused by the imperfection of the regulatory framework governing the negotiation process. The agreement, in fact, loses its normative component, which makes them the most vulnerable legal acts.

In general, the collective agreement basically supplemented and concretized the content of the sectoral and regional agreements (48.8\% and 31.7\%, respectively), and also repeated some of their provisions $(31.2 \%$ and $27.4 \%$, respectively), which positively affected on the organization and conduct of the negotiation process.

Awareness of trade union personnel on UNC technology. Successful holding of the negotiation process is largely predetermined by information work at various levels of social partnership. The extent to which trade union leaders are informed about the main legal acts depends on their position in the negotiations, their ability to defend the interests of workers.

It is obvious that the knowledge of professional leaders about the main legal documents predetermines their thoroughness in work, reduces the risk of making wrong management decisions. The greater the degree of awareness of the trade union leader, the greater is his ability to coordinate his actions and chances for success in the negotiation process.

In the course of the study, it was established that the number of people informed about the UNC technology remains at about the same level. At the same time, the share of those who are not informed about UNC technology is decreasing. The study showed that representatives of large metropolitan cities more often than the average in the sample are informed about the UNC mechanisms. Representatives of regional and district centers, as well as cities with a population of less than 300 thousand people turn out to be the least informed than the average for the sample. A significant correlation is observed between the knowledge of the trade union leader and his status as a professional worker, as well as his position. With an increase in the length of service of trade union work, the number of those who are informed about the UNC mechanisms increases. However, among the 


\section{ENTREPRENEURSHIP AND SUSTAINABILITY ISSUES}

ISSN 2345-0282 (online) http://jssidoi.org/jesi/ 2019 Volume 7 Number 1 (September) http://doi.org/10.9770/jesi.2019.7.1(8)

"uninformed" there is a reverse trend. With the increase in length of service, the number of those respondents who unequivocally answer "No" increases. Obviously, the age of the respondents, their conservatism in acquiring new information, have a great influence. Thus, the respondents of the older age group (from 50 years and above), more often indicated that they do not have information on the UNC mechanisms.

The structure of the factors determining the success of the trade union leader in the negotiations. An analysis of a group of factors that significantly influence the preparation and conduct of negotiations by the trade union leader in the system of social partnership showed that they were almost proportionally distributed between the subjective and objective character with a shift in focus on the objective ones. Despite this, it was the subjective factor "practical experience" $(20.4 \%)$ that was put in the first place. Also, the subjective factor "knowledge" ranked third (17\%). This suggests the need for continuous development of trade union leaders, the passage of advanced training courses, the use of various, including distance learning, online and offline training (Moore \& Pearson, 2017.). The most important factor was the support of the team (14.2\%). Undoubtedly, an active, cohesive team can provide the trade union leader with real help and support in defending their rights. An additional argument in achieving the desired results during the negotiation process will be the support of higher authorities (12.5\%).

In the course of the focus group's work, the extent to which trade union leaders adopted the principles of a single negotiation campaign to protect the interests of workers was discussed and emphasis was placed on the need to constantly bring the UNC system in line with the new Russian social and economic realities. To this end, obstacles to the conduct of the negotiation process were identified, and the main ways were formulated that contribute to the development of the system of protection of the organization's employees (the region).

There were no significant differences in the answers of respondents in the sphere of professional activity by experts. Solving issues related to the regulation of wages, of course, prevails. After all, workers and employers have different bargaining power; in the search and matching model (Diamond, 1982), wages are determined during the bargaining process between the parties to the negotiation process. Among the priorities were the increase in the subsistence minimum, the increase in the average salary and the need to strengthen control, both from the trade unions and from the state bodies. It was revealed that in the general mass of the respondents the point of view prevails that social protection issues should be solved, first of all, independently - each at his own level.

In general, a certain imbalance developed in the studied subsamples. The reason for this imbalance is largely predetermined by the peculiarities of the negotiation process in the sectoral and territorial context. Not the last place in the influence on the distribution of answers has the execution of laws regulating the socio-economic situation of workers.

The overall assessment of the weaknesses in the negotiation process makes it possible to identify the main areas of development of the UNC principles in protecting the interests of workers: social responsibility of employers and the state (rising unemployment leads to increased state budget expenditures) (Dudin, Lyasnikov \& Horikov, 2013; Androniceanu et al., 2019), on the labor market, the heterogeneity of agents causes friction leading to the simultaneous coexistence of vacancies and unemployment (Romer, 2006); stabilization and expansion of the protective functions of trade unions; improved regulatory framework; informational support of the negotiation process. 


\section{ENTREPRENEURSHIP AND SUSTAINABILITY ISSUES}

ISSN 2345-0282 (online) http://jssidoi.org/jesi/ 2019 Volume 7 Number 1 (September) http://doi.org/10.9770/jesi.2019.7.1(8)

\section{Conclusions}

Improving the efficiency of the negotiation process in the system of social partnership is the main direction of the realization of the legitimate rights of workers to uphold their interests. In the course of the study, the hypothesis was confirmed: the success of a unified transient campaign is completely dependent on the local implementation of concrete actions by the parties to social partnership on social protection of the interests of workers. The most important condition is the creation of a harmonious system that takes into account the interests of all parties to the negotiation process at various levels of social partnership.

UNC implementation today remains one of the main strategic directions of the development of the social partnership system. In the course of the study, it was found that the demand for UNC in a regional context is still limited. Due to the fact that the interests of many trade union leaders on the ground are not yet connected with the organization of comprehensive work within the framework of the implementation of the basic principles of the negotiation campaign. The deterrent factors here are, of course, the desire for independence and independence of a number of trade union leaders.

Among the characteristics of the work of trade union leaders in mastering the principles of the UNC in protecting the interests of workers, a special place belongs to the level of information support of the union work in the field, as well as the degree of professionalism of trade union personnel. Among the main indicators that determine the level and quality of information work in the field, the degree of awareness of the chairmen of trade union committees on the implementation of agreements at various levels was considered.

It is important to note that there is a significant discrepancy between the degree of awareness of respondents about the content of the agreement and its implementation. Weak awareness in the Russian trade unions reduces the effectiveness of the implementation of a single negotiating company, which in turn negatively affects the system of the formation of social partnership.

The practice of implementing agreements (regional and sectoral) shows that the trade union side here is faced with unfulfilled commitments to reduce wage arrears and economic growth. The problem of their implementation and the responsibility of the parties is directly dependent on the collective representation of workers from sectors and professions. Imperfection of the regulatory framework governing the negotiation process has a negative effect on the effectiveness of social partnership. Agreements, in essence, lose their regulatory component, making them the most vulnerable legal acts.

To reach the efficiency increasing in the negotiation process in the social partnership system, the following ways have been proposed:

1. To improve the information system for providing trade union leaders.

2. Issues of social protection should be addressed, first of all, independently - each at his own level.

3. To stimulate trade union leaders to conduct integrated work within the framework of the implementation of the basic principles of the negotiation campaign, focusing on the increase in wages, the subsistence minimum and the need to strengthen control, both from the trade unions and from government bodies.

4. The development of trade union leaders to focus on gaining knowledge and practical experience in negotiating, the study of the regulatory framework. At the same time, they need to learn how to enlist the support of the team from the higher authorities.

These measures will improve the efficiency of the negotiation process in the system of social partnership. 


\section{ENTREPRENEURSHIP AND SUSTAINABILITY ISSUES}

ISSN 2345-0282 (online) http://jssidoi.org/jesi/ 2019 Volume 7 Number 1 (September) http://doi.org/10.9770/jesi.2019.7.1(8)

\section{References}

Androniceanu, A.2019a. The social sustainability of smart cities: urban technological innovation, big data management, and the cognitive internet of things, Geopolitics, History, and International Relations 11(1): 110-115. https://doi.org/10.22381/GHIR11120197

Androniceanu, A., 2019b. A managerial approach to Romania's security strategy with NATO, Journal of Security and Sustainability Issues, 8(3): 423-433. http://doi.org/10.9770/jssi.2019.8.3(11)

Androniceanu A., Gherghina, R., Ciobănaşu, M. 2019. The interdependence between fiscal public policies and tax evasion, Administratie si Management Public, (32), 32-41. https://doi.org/10.24818/amp/2019.32-03

Baxter, R.J.; Holderness, D.K.; Wood, D.A. 2016. Applying basic gamification techniques to it compliance training: evidence from the lab and field, Journal of information systems, 30(3): 119-133. https://doi.org/10.2308/isys-51341

Belle, N.; Cantarelli, P. 2015. Monetary Incentives, Motivation, and Job Effort in the Public Sector: An Experimental Study With Italian Government Executives, Review of Public Personnel Administration, 35(2): 99-123. https://doi.org/10.1177/0734371X13520460

Bernardi, A. 2019. The capability approach and organizational climate as tools to study occupational health and safety, Insights into Regional Development, 1(2): 155-169. https://doi.org/10.9770/ird.2019.1.2(6)

Blossfeld, H.P.; Huinink, J. 1991. Human Capital Investments or Norms of Role Transition? How Women's Schooling and Career Affect the Process of Family Formation, American Journal of Sociology, 97(1).

Bondaletova, N.F.; Kirillov, N.P.; Maslikov, V.A.; Nazarenko, S.V. 2018. Modern innovations in the system of Russian education as a factor of its effectiveness, Espacios, 39(49): 23.

Borisov, A.; Narozhnaia, D.; Tarando, E.; Vorontsov, A.; Pruel, N.; Nikiforova, O. 2018. Destructive motivation of personnel: a case study of Russian commertcial companies, Entrepreneurship and Sustainability Issues, 6(1): 253-267. http://doi.org/10.9770/jesi.2018.6.1(16)

Bronkhorst, B.; Steijn, B.; Vermeeren, B. 2015. Transformational Leadership, Goal Setting, and Work Motivation: The Case of a Dutch Municipality, Review of Public Personnel Administration, 35(2): 124-145.

Buley, N.V.; Bondaletov, V.V.; Makushkin, S.A.; Bondaletova, N.F.; Kozyrev, M.S. 2016. Public administration and municipal governance and its significance for a modern democratic society, International Journal of Economics and Financial Issues, 6(8S): 220-224.

Buley, N.V.; Demchenko, T.S.; Makushkin, S.A.; Vinichenko, M.V.; Melnichuk, A.V. 2016. Human resource management in the context of the global economic crisis, International Journal of Economics and Financial Issues, 6(8S): 160-165.

Chulanova, O.L.; Korosteleva, D.A. 2017. Methodical aspects of updating of "management of talents" technology in work with a personnel pool of the organizations, Human resource management and intellectual resources in Russia, 4(6): 15.

Ciobanu, A, Androniceanu A., Lazaroiu, G. 2019. An integrated psycho-sociological perspective on public employees' motivation and performance. Frontiers in Psychology, 10:36. https://doi.org/10.3389/fpsyg.2019.00036

Coordination of European, national \& regional initiatives. 2017. Retrieved from: https://ec.europa.eu/digital-single$\underline{\text { market/en/coordination-european-national-regional-initiatives. }}$

Cranford, C.J.; Vosko, L.F.; Zukewich, N. 2003. Precarious Employment in the Canadian Labor Market: A Statistical Portrait, Just Labour, 3: 9.

Demchenko, T.S.; Karácsony, P.; Vinichenko, M.V.; Demchenko, M.V.; Melnichuk, A.V. 2018. Youth involvement in social control of the implementation of the youth personnel policy in the company management system, Espacios, 38(21): 8.

Demeneva, N.A. 2007. The European Community in combating discrimination on the basis of sex, Bulletin of the State University of Communications and Information Technologies, 18: 111-117.

Diamond, P.A. 1982. Wage Determination and Efficiency in Search Equilibrium, Review of Economic Studies, 49: $217-227$. 


\section{ENTREPRENEURSHIP AND SUSTAINABILITY ISSUES}

ISSN 2345-0282 (online) http://jssidoi.org/jesi/ 2019 Volume 7 Number 1 (September) http://doi.org/10.9770/jesi.2019.7.1(8)

Dudin, M.N.; Lyasnikov, N.V.; Horikov, Yu.V. 2013. Brain factor and its stating role in enterprises' competitive recovery, European Researcher, 38(1-1): 15-19.

Dunlop, J.T. 1958. Industrial Relations Systems. New York: Henry Holt and Winston: 416.

Duval, R.; Furceri, D. 2018. The Effects of Labor and Product Market Reforms: The Role of Macroeconomic Conditions and Policies, IMF Economic Review, 66(1): 31-69.

Frolova, E.V.; Medvedeva, N.V.; Kabanova, E.E.; Kurbakova, S.N.; Vinichenko, M.V. 2016. Social Partnership in Russia: Prerequisites, Problems and Trends, Journal of Advanced Research in Law and Economics, 2(16): 221 - 228. https://doi.org/10.14505/jarle.v7.2(16).05 Retrieved from: http://www.asers.eu/journals/jarle/jarle-issues

Fudge, J. 2011. The Precarious Migrant Status and Precarious Employment: The Paradox of International Rights for Migrant Workers, Metropolis British Columbia: Centre of Excellence for Research on Immigration and Diversity Working Paper, 11-15: 12.

Hyman, R. 1995. Industrial Relations in Europe: Theory and Practice, European Journal of Industrial Relations, 1(1): 17-46.

Kalleberg, A.L. 2014. Measuring Precarious Work, A Working Paper of the EINet Measurement Group. Retrieved from: https://cpb-usw2.wpmucdn.com/voices.uchicago.edu/dist/5/1068/files/2018/05/einet_papers_kalleberg-1owgfyz.pdf

Kataeva, V.I.; Kaurova, O.V.; Koludarova, S.V.; Sulyagina, J.O.; Fomicheva, T.V.; Kryuko, E.M. 2015. Barriers of inequality in social institutions of Russia, Biosciences Biotechnology Research Asia, 12(3): 2813-2820.

Kirillov, A.V.; Ushakov, D.S.; Vinichenko, M.V.; Makuchkin, S.A.; Melnichuk, A.V. 2017. Career Opportunities for the Management's Personnel Reserve, Eurasian Journal of Analytical Chemistry, 12(5b): 723-733. https://doi.org/10.12973/ejac.2017.00205a

Liu, B.; Perry, J.L. 2016. The Psychological Mechanisms of Public Service Motivation: A Two-Wave Examination, Review of Public Personnel Administration, 36(1): 4-30.

Lorincová, S.; Hitka, M.; Bajzíková, L'.; Weberová, D. 2019. Are the motivational preferences of employees working in small enterprises in Slovakia changing in time, Entrepreneurship and Sustainability Issues, 6(4): 1618-1635. https://doi.org/10.9770/jesi.2019.6.4(5)

Moerel, H. 1994. The Study of Labour Relations. Labour Relations in Transition, Nijmegen: Institute for Applied Social Sciences: 1-7.

Moore, K.A.; Pearson, B.J. 2017. Soft skills in an online class, Horttechnology, 27(5): 583-585.

Mühlberger, U. 2009. The Social Effects of Precarious Work, Research Report, Universität Wien. Retrieved from: https://static1.squarespace.com/static/559921a3e4b02c1d7480f8f4/t/5862fb6bff7c501ec52c6162/1482881901267/Mhlberger.pdf

Mysnik, V.G.; Marchelya, N.V. 2014. Discrimination of hired workers in the Russian labour market, International scientific research journal, 4(23), 3: 60-61.

Oseev, A.A.; Dudueva, F.A.; Karácsony, P.; Vinichenko, M.V.; Makushkin, S.A. 2018. The peculiarity of the ethno-social conflicts in the Russian labor market: comparative analysis of Russia, Great Britain and Germany, Espacios, Especial, 39(22): 12.

Policies and Regulations to Combat Precarious Employment. 2011. International Labour Organization. Retrieved from: https://www.ilo.org/wcmsp5/groups/public/@ed_dialogue/@actrav/documents/meetingdocument/wcms_164286.pdf

Precarious Employment in Europe. Part 1: Patterns, Trends and Policy Strategy. 2016. European Parliament. Retrieved from: http://www.europarl.europa.eu/RegData/etudes/STUD/2016/587285/IPOL_STU(2016)587285_EN.pdf

Rodgers, G. 1989. Precarious Jobs in Labour Market Regulation: The Growth of Atypical Employment in Western Europe, Brussels: International Labour Organisation.

Rogach, O.V.; Frolova, E.V.; Kirillov, A.V.; Bondaletov, V.V.; Vinichenko, M.V. 2016. Development of favourable learnıng environment and labor protection in the context of harmonization of social interaction of educational system objects, IEJME-Mathematics Education, 11(7): 2547-2558. 


\section{ENTREPRENEURSHIP AND SUSTAINABILITY ISSUES}

ISSN 2345-0282 (online) http://jssidoi.org/jesi/ 2019 Volume 7 Number 1 (September) http://doi.org/10.9770/jesi.2019.7.1(8)

Rogach, O.V.; Frolova, E.V.; Ryabova, T.M. 2018. Theory of "trust" in the focus of expectation study concerning educational space key actors, European Journal of Contemporary Education, 7(2), 392-399.

Rogach, O.V.; Ryabova, T.M.; Frolova, E.V.; Evstratova, T.A.; Kozyrev, M.S. 2018. Social and psychological climate in state, Espacios, 39(11): 19.

Romer, D. 2006. Advanced Macroeconomics, 3rd ed., New York: McGraw-Hill/Irwin.

Salamon, M.W. 1987. Industrial Relations: Theory and Practice, London: Prentice-Hall International: 580.

Schmidt, M. 2002. News of Atypical Work in Germany: Recent Developments as to Fixed-term Contracts, Temporary and Part-time Work, German Law Journal, $7 . \quad$ Retrieved from: https://static1.squarespace.com/static/56330ad3e4b0733dcc0c8495/t/56b97d9fcf80a1b8c85c16e6/1454996895751/GLJ Vol 03 No 07 S chmidt.pdf

Sciarra, S. 2004. Employment Policy and the Regulation of Part-time Work in the European Union, Cambridge, UK; New York: Cambridge University Press.

Vasile, O., Androniceanu, A. 2018. An overview of the Romanian asylum policies. Sustainability 10(5), 1461; p. 1-22. Doi: https://doi.org/10.3390/su10051461

Veretekhina, S.V.; Zhuravlyov, M.S.; Shmakova, E.G.; Soldatov, A.A.; Kotenev, A.V.; Kashirin, S.V. 2018. Analog Sound Signals Digitalization and Processing, Modern Journal of Language Teaching Methods, 8(3): 39-54.

Vinichenko, M.V.; Karácsony, P.; Demchenko, T.S.; Melnichuk, A.V.; Makuchkin, S.A. 2017. Satisfaction of Employees of Moscow Region Organizations by Implementation of Youth Personnel Policy, Eurasian Journal of Analytical Chemistry, 12(5b): 697-704. https://doi.org/10.12973/ejac.2017.00203a

Vinichenko, M.V.; Kirillov, A.V.; Frolova, E.V.; Kaurova, O.V.; Makushkin, S.A. 2016. Monitoring of working conditions and the nature of their influence on health of students and academic staff, International Journal of Environmental and Science Education, 11(11): 45644577 .

Vinichenko, M.V.; Kirillov, A.V.; Maloletko, A.N.; Frolova, E.V.; Vinogradova, M.N. 2018. Motivation of University Senior Staff in the Process of Restructuring Higher Education Institutions, Croatian Journal of Education, 20(1): 199-232. https://doi.org/10.15516/cje.v20i1.2571

World Employment and Social Outlook. 2015. The Changing Nature of Jobs, International Labour Organization. Retrieved from: https://www.ilo.org/global/research/global-reports/weso/2015-changing-nature-of-jobs/lang--en/index.htm 
Mikhail V. VINICHENKO

ORCID ID: 0000-0003-1973-3485

Dmitry S. KLEMENTYEV

ORCID ID: 0000-0002-7767-9678

Marina V. RYBAKOVA

ORCID ID: 0000-0002-7610-3896

Maksim A. MALYSHEV

ORCID ID: 0000-0002-4672-6005

Natalia F. BONDALETOVA

ORCID ID: 0000-0002-9736-4892

Inna V. CHIZHANKOVA

ORCID ID: 0000-0002-2312-0481

Register for an ORCID ID:

https://orcid.org/register

Copyright (C) 2019 by author(s) and VsI Entrepreneurship and Sustainability Center

This work is licensed under the Creative Commons Attribution International License (CC BY).

http://creativecommons.org/licenses/by/4.0/

(C) (i) Open Access 